\title{
Driving Forces behind Regional Retail Network and Thoughts on Innovative Development
}

\author{
Mingxiao Zhao ${ }^{1}$ \\ ${ }^{1}$ Industrial and Commercial Management Department, Dalian Vocational and Technical College, Dalian, China
}

\begin{abstract}
The past decade of innovation in the retailing industry has formed a general framework for regional retailing in China. Such achievement is a result of reckless efforts and the nature of business. This paper focuses on future regional retailing based on the motivation behind the existing regional retailing network and proposes suggestions in terms of market positioning, competitiveness, regional alliance, and technical support.
\end{abstract}

\section{Introduction}

Since the first regional retailing alliance was established in September 2017, the regional retailing industry of China has been pressing ahead with a new form of network in shape. According to Kantar Worldpanel, the major retailers of Modern Trade had a market share of up to 8.3 in the first quarter of 2019 (as shown in Table 1), indicating that regional retailing is shaping the retailing structure of China.

The List of China's Top 100 Retail Enterprises in 2018 released by the Commerce Federation in 2019 showed that the regional enterprises had a faster growth rate than that of trans-regional enterprises. Among the 67 retail enterprises in the list with an asset of over 10 billion, there are only 7 online retail enterprises while the rest 60 are physical retail enterprises, including 31 trans-regional enterprises and 29 intra-regional enterprises. Compared with 2017, there were 6 less trans-regional enterprises while four more intra-regional enterprises in 2018. The growth rate of 31 cross-regional enterprises decreased by $16.2 \%$ year on year while the regional enterprises increased by $16.0 \%[1]$.

Table1. Market share of major retailers of modern trading in Q1 of 2019

\begin{tabular}{|c|c|c|c|c|}
\hline & $\begin{array}{c}\text { 52 weeks as } \\
\text { of March 23, } \\
\mathbf{2 0 1 8}\end{array}$ & $\begin{array}{c}\text { 52 weeks as } \\
\text { of March 23, } \\
\mathbf{2 0 1 9}\end{array}$ & $\begin{array}{c}\text { Q1 in } \\
\mathbf{2 0 1 8}\end{array}$ & $\begin{array}{c}\text { Q1 in } \\
\mathbf{2 0 1 9}\end{array}$ \\
\hline Sun Art & 8.4 & 8.3 & 8.7 & 8.3 \\
\hline Auchan (China) & 1.3 & 1.3 & 1.3 & 1.2 \\
\hline RT-Mart & 7.1 & 7 & 7.5 & 7.2 \\
\hline CR Vanguard & 6.7 & 6.7 & 7.1 & 7 \\
\hline Wal-Mart & 5.3 & 5.3 & 5.4 & 5.1 \\
\hline Yonghui & 3.4 & 4 & 3.8 & 4.2 \\
\hline Carrefour & 3.2 & 2.9 & 3.1 & 2.8 \\
\hline Bailian & 2.7 & 2.5 & 2.5 & 2.4 \\
\hline WuHan Selline & 1.8 & 2.1 & 2 & 2.3 \\
\hline Wumart & 1.9 & 1.9 & 1.8 & 1.9 \\
\hline SPAR & 1.4 & 1.5 & 1.4 & 1.5 \\
\hline $\begin{array}{c}\text { Better Life } \\
\text { (including ancheng } \\
\text { Department Store) }\end{array}$ & 1.3 & 1.4 & & \\
\hline
\end{tabular}

Source: Kantar Worldpanel
In addition, nationally renowned brands like Letus, Pangdonglai of Henan Province, HUIYOU-mart of Hebei Province, Xiangjiang Department Store of Hunan Province, Renrenle Market of Shenzhen, and Chengdu Hongqi Chain Co., Lted, are leading regional retailers through in-depth market exploitation, with aggregation advantages. They are widely popular among local people and have made major contribution to urbanization and improved quality of local people's life.

Table2. Top 100 Retailers of China in 2018 Released on September 2019

\begin{tabular}{|c|c|c|}
\hline No. & Brand & Regional Advantages \\
\hline 1 & Tmall & Online Retail Enterprise \\
\hline 2 & JD.com & Online Retail Enterprise \\
\hline 3 & Pinduoduo & Online Retail Enterprise \\
\hline 4 & Suning.com & Trans-regional Enterprise \\
\hline 5 & Dashang & Liaoning Province \\
\hline 6 & Gome & Trans-regional Enterprise \\
\hline 7 & CR Vanguard & Trans-regional Enterprise \\
\hline 8 & RT-Mart & Trans-regional Enterprise \\
\hline 9 & Vipshop & Online Retail Enterprise \\
\hline 10 & Wal-Mart (China) & Trans-regional Enterprise \\
\hline 11 & Yonghui & $\begin{array}{l}\text { Top Company in Fujian and } \\
\text { Chongqing }\end{array}$ \\
\hline 12 & $\begin{array}{l}\text { Chongqing General } \\
\text { Trading }\end{array}$ & Chongqing \\
\hline 13 & Hefei Department Store & Anhui Province \\
\hline 14 & Lianhua Supermarket & Shanghai \\
\hline 15 & Wumart & Beijing \\
\hline 16 & Carrefour (China) & Trans-regional Enterprise \\
\hline 17 & Eurasia & Jilin Province \\
\hline 18 & Better Life & Hunan Province \\
\hline 19 & $\begin{array}{l}\text { Wuhan Department } \\
\text { Store }\end{array}$ & Hubei Province \\
\hline
\end{tabular}




\begin{tabular}{|l|l|l|}
\hline 20 & Silver Plaza & Shandong Province \\
\hline 21 & Wangfujing & Beijing \\
\hline 22 & $\begin{array}{l}\text { ShijiaZhuang Beiguo } \\
\text { Renbai }\end{array}$ & Hebei Province \\
\hline 23 & Zhongbai Holdings & $\begin{array}{l}\text { Middle and Western Part of } \\
\text { China }\end{array}$ \\
\hline 24 & Yintai Business & Trans-regional Enterprise \\
\hline 25 & $\begin{array}{l}\text { Guangzhou Department } \\
\text { Store }\end{array}$ & Guangdong Province \\
\hline 26 & $\begin{array}{l}\text { Rainbow Department } \\
\text { Store }\end{array}$ & Guangdong Province \\
\hline 27 & Liqun & Shandong Province \\
\hline 28 & Jiajiayue & Shandong Province \\
\hline 29 & Yantai Zhenhua & Shandong Province \\
\hline 30 & Red Star Macalline & Trans-regional Enterprise \\
\hline
\end{tabular}

\section{Driving factors behind the innovative regional retailing network of China}

The retailing industry of China varies with geographical features, with most retail business thriving in only certain regions like first-tier cities, third or fourth-tier cities characterized by strong purchasing power. President Pei Liang of the China Chain Operation Association said that China's retail market can be divided into the dual structure of developed and developing markets. The market division will keep its momentum in future retailing market, i.e., the retail market of the first-tier cities will be tangled by fierce and diverse competitions while the regional retail market of the third and fourth-tier cities will mature step by step at their own pace[2].

\subsection{Distinct geographical structures and consumption habits leading to different regional markets}

The vast land of China, drastic climate differences across the country, ethnic characteristics formed by regional history and economic gaps between regions work together to form their distinct consumption habits and shape the features of regional retailing of China.

The northern winter is long and people prefer salty diet. The south is warm and humid, and people there like taking soup. Shaanxi can't live without noodles and flour-made food, Shanxi is keen on sour-tasted food, and Hubei and Sichuan are crazy for spicy food... This is just a difference in diet. The economy of the east far exceeds that of the northwest region, based on which cities of China are classified into first, second, third, fourth and fifth tier. People in first-tier cities pays more attention to quality and convenience while in third-and fourth-tier cities quality but cheap products are more popular. Young people are leaving villages for cities, with the elderly and the middleaged groups as the main targets of service in the remote area.

The retail industry can't live without people and their needs. Therefore, regional characteristics caused by differences in geography, culture and diet have posed huge challenges to trans-regional retail. On the contrary, regional retailers engaging in local area for years have gained an accurate understanding of consumers' needs, endowing it with advantages in regional competition, which in turn, has attracted and developed numerous regional retailers.

Usually, foreign-funded enterprises entering the Chinese market favor first-tier cities because these cities are highly similar with the cities where foreign-funded enterprises started their business, especially in purchasing power, which creates ideal conditions for them to operate across regions.

\subsection{The trans-regional operation having no overwhelming advantages over other models, with mounting pressures on the construction of core competitiveness}

In cross-regional operation, retail enterprises need time to familiarize themselves with the local market to attract regional customers. In particular, they need to take a share in scarce but thriving business districts and make the right decision concerning site selection. Therefore, there are only a few retail enterprises that truly set foot in provinces across the country and develop into large chains. The conflict between new comer and local power exerts huge pressure upon enterprise to build its core competitiveness, which is difficult to fully set up within a short time.

\subsubsection{Pressure on the construction of supply chain}

As a low margin industry, the core competitiveness of the retail industry lies mainly in the construction of the "supply chain" with focus on speed and operation cost. Trans-regional enterprises are caught right by a backward "supply chain", thus unable to bring scale benefits into play. A recent example is CR Vanguard who gave up the Shandong and Beijing market two years ago mainly because the small northern market was not enough to lower supply chain cost, threatening the development of the company and causing huge losses. CR Vanguard's poor matching of resources in Beijing and Shandong markets, chaotic management and lack of decent logistics have further deepened CR Vanguard's crisis in the northern market[3].The compromise of CR Vanguard further enhanced the dominance of Jiajiayue and Wumart in Shandong and Beijing respectively.

\subsubsection{Pressure on resource distribution}

For retail enterprises striving to build up competitive edges in a region, the process to perfect the network takes time, especially in site selection, recruitment, construction of supply chain and customer cultivation. The huge cost coupled with difficulties of site selection in a mature business district overwhelms the distribution of regional resources. Therefore, it's not easy to set a firm footing in a new region.

Enterprises would turn to M\&A or cooperation with local leading companies for rapid expansion into a new regional market, which allows enterprises to benefit from 
the mature resources of its counterpart to speed up expansion. For example, Yonghui adopted this strategy to buy Zhongbai from Wuhan, seek cooperation with ParknShop, become a shareholder of Hongqi Chain Store, negotiate with Jiangxi Wangzhongwang in an attempt to speed up expansion into the Jiangxi market[4].

\subsubsection{Pressure on manpower management}

One more problem confronting trans-regional business lies in insufficient manpower to support overtly accelerated expansion. The headquarter could offer support to stores nearby. However, for stores far away from the headquarter, mismanagement could take place caused by daily changes of market, inaccurate understanding of regional characteristics, incompetency of managers and delayed communication between the branch and the headquarter.

\subsection{Development of centralized regional markets more consistent with the scale economy giving rise to the aggregation effect}

\subsubsection{Aggregation effect on enterprise influential power}

Through years of regional market development, retail enterprises have gone deep into the hinterland of consumption, fully integrated into the local society with a decent understanding of the purchasing habits of residents. The deeper into the regional market, the more retailers understand consumers, the more they can gain a firm foothold, and the easier it is to expand outlets. However, too many outlets would form an aggregation effect on the influence and reputation of enterprises, making them more influential in the region. The whole process is regarded as a virtuous circle. Deep cultivation of the regional market ahead of competitors would also make it easier for enterprises to enjoy more opportunities with a greater share of market in the relatively mature business circle and more support from local government.

\subsubsection{Prominent regional scale effect}

Retailers' understanding of regional characteristics forms valuable experience, which would lead to learning scale effect in regional expansion. Regional retailers equipped with sufficient close-distance outlets could support the construction of the supply chain, and it is easier for them to exert the scale effect of the supply chain. From an economic point of view, the more concentrated the regional competitiveness, the lower the marginal cost, and the lower the average cost, which is mainly reflected in scale procurement, logistics distribution, personnel training, marketing, publicity, etc.

\section{Some thoughts on the innovative development of the regional retail market}

Since the reform and opening up 40 years ago, China has been pressing ahead with the development of the retail market. There are more Chinese voices in international business, and Chinese retail practitioners are advancing with the times. Investment from foreign-funded enterprises in 2019 shows that China's retailers have stepped into a new chapter on their way forward. It is great that retail enterprises are bigger and stronger now, but what they are truly pursing is to provide consumers with a healthy and convenient environment for shopping.

\subsection{Accurate positioning instead of simply following the trend}

Regional retail enterprises are characterized by accurate analysis of location-based consumption characteristics to identify the positioning of enterprises. The enterprise positioning relies on the understanding of consumer needs and differentiate the positioning of core products and services to establish its unique position among consumers and convey it to the target customers.

Regional retail enterprises usually lack confidence in themselves, and tend to follow the trend initiated by leading companies. However, the best practices of leading companies didn't necessarily fit the followers. For example, the Xiangjiang Department Store of Hengyang in Hunan borrowed experiences of Carrefour and Pangdonglai, and was considered an enterprise most resembling Pangdonglai. However, it finally walked out of Pangdonglai's shadow and created its own characteristics through learning, in-depth marketing and consumer surveys[5].

Every enterprise has its distinct background and culture. As the starters of enterprises have their own styles, simply following existing practices doesn't necessarily guarantee a happy ending. Enterprises need to identify the ideal product, service and model based on its specific realities.

\subsection{Building core competitive force based on the nature of business}

\subsubsection{Focus on the quality of product}

The retail industry needs to build up close ties with customers through products to reveal features of regional enterprises via major products, differentiate its position and guide consumers from a perspective ahead of time.

To start with, enterprises need to optimize commodity structure to maintain the elimination rate and up-to-date rate at a certain level by enriching product portfolios. It is impossible for enterprises to meet every need of customers. With the increase of individualized needs, enterprises have started to look for sticky products.

Secondly, enterprises need to develop commodities of distinct characteristics and cultivate it into the symbol of 
the company that brings profits and customers. The development of distinctive commodities is similar to products popular online, or products with a large consumption base of target consumers.

Thirdly, the development of exclusive brands enables enterprises to integrate corporate brand with commodity brand to enhance its core competitiveness. The management of exclusive brands forms a part of strategic enterprise management that requires time and an overall understanding of the whole picture. Enterprises need to position its exclusive brands from an overall perspective while monitoring the whole procedures from $\mathrm{R} \& \mathrm{D}$, production to marketing. Enterprises need to identify products of cost efficiency and regional characteristics based on its procurement and management capacities instead of pursuing for cheap products.

\subsubsection{Improving services based on regional edges}

Regional retailers are confronted by two categories of competitors, one is large-scale top companies operating across regions, and the other is local enterprises. Transregional enterprises tend to have problems in management due to geographical disadvantages. However, local enterprises are favored by local people, especially the elderly, despite an absence of systematic and unified management.

Regional retail enterprises need to distinguish itself from the two categories of competitors via superior management capacity, and offer customers with better services and integrated solutions while concentrating resources and enhancing the development of headquarter.

First, enterprises need to upgrade the environment for shopping. Make the mall a stage to display products and deliver wonderful experience to customers as the appreciation of beauty or even art would attract customers. Cultivate the mall into a handy place for shopping, with tips and sharing of information available everywhere in the mall as well as assistance and help offered to them anytime and anywhere.

Second, take the role of housekeeper for customers. The enterprises should offer home delivery, on-site cooking, food processing for free, product return, product upgrading and other services based on product management. Also, they need to rely on technical upgrading and big data to cultivate centers of distinct features from the perspective of customers as a guide, assistant, and housekeeper for customers.

\subsection{Forming alliances with other regional counterparts}

Since the IBMG Business Think Tank launched the China Retail Regional Alliance in 2017,other platforms of regional cooperation such as Qilu Business Alliance, Zhejiang Xiaoyi Regional Alliance, Taiyuan Regional New Retail Platform, Multi-point Alliance and Jingdong Empowering Regional Brands have emerged, aiming at assisting regional enterprises in serving as a complement for each other, resource sharing and information exchange to form scale advantages, empower enterprises and promote the retail industry to achieve common prosperity.

Today, retail enterprises are confronted by a market of fierce competitions, with integrated technical requirements and rapid technological iteration. It will take a long time for regional retail enterprises to succeed on their own. Instead, it would make it easier for regional retail enterprises to gather for sharing and mutual benefits.

Proximity in location, target consumers and operating environment enables regional enterprises to share similar back-office supply chains, front-office management systems and suppliers. The formation of an alliance offers regional enterprises the strength to concentrate resources for building up core competitiveness.

Regional retail enterprises need to consider the following three issues when forming cooperative relationships:

First, though the alliance aims at complementing each other, the enterprises need to keep their vitality and characteristics instead of maintaining the status quo, which would cause greater losses than benefits.

Second, the alliance strives to improve services to meet the changing material and spiritual needs of consumers. Also, the alliance needs to maintain existing competitions and avoid monopoly, which would damage motivations of enterprises and the interests of consumers.

Third, enterprises in the alliance need to figure out the purpose and edges of the organization, and make clear the integration of resources and individual responsibilities, giving a full play to the role of the alliance.

\subsection{Promoting regional development using information technology}

Innovations and revolutions in the new retail era cannot take place without the assistance of information technology, which is not only big data, but also includes block chain, artificial intelligence and cloud computing, assisting enterprises in intelligent transformation and the creation of a full channel service platform online and offline for two major goals:

First, construction of an accurate and efficient service platform using information technology

Technologies like big data and cloud computing can be used to meet users' needs and provide solutions. Customized products using AI big data make personalized services possible, while intelligent shelves and selfservice cashier settlement systems improve efficiency.

Second, offer interactive experience using information technology.

By transforming information technology, enterprises create an ecosystem of supply chain, speed up service to improve customers' experience, and allow interactions during the service. Wumart carries out an all-round digital transformation in 2019 through the construction of a digital platform to improve consumers' experience in an efficient way. RT Mart borrows experience from Boxer of innovative technology and logistics access capability. Stores have been renovated one after another, with onehour service covering hundreds of millions of consumers aiming at improving consumers' shopping experience.

Regional retailing represents a lifestyle, in which 
enterprises and consumers in the region rely on each other. The development of regional retailers should always be accompanied by its regional characteristics instead of blindly imitating others or in pure pursuit of speed. The regional retailers need to contribute to the development of the region while benefiting from it, thus truly involved in the regional development.

\section{Reference}

1. China General Chamber of Commerce, China National Commercial Information Center: Top 100 retailers of China in 2018,http://www.cgcc.org.cn/xxfb/89853.htm,Sep2019

2. Liang Pei: In the next five years, a large number of regional retail enterprises will emerge, China Business Network https://www.yicai.com/news/100038650.html,Oct2018

3. Yanli Wang: Wu Mart, JiaJiaYue take over CR Vanguard: The advance and retreat of regional retail, Retail boss internal reference APP, Mar-2019

4. Siyao Zhang: Yonghui want to buy Jiangxi Wangzhongwang To compensate for late entry to the market and lost opportunities, Retailobservation,http://news.winshang.com/html/06 5/6753.html,Apr-2019

5. Ruiqi Li: Xiangjiang Department Store: The characteristics of Regional retailer,Linkshop,http://www.linkshop.com.cn/web/a rchives/2019/430564.shtml,Sep-2019 